\title{
Do Regional Trade Agreements Increase Bilateral Greenfield Investment?
}

\author{
Badassa Wolteji Chala \\ Kangwon National University, Chuncheon, Republic of Korea \\ Hyun-Hoon Lee \\ Kangwon National University, Chuncheon, Republic of Korea
}

\begin{abstract}
Using bilateral flow data among 25 Organizations for Economic Co-operation and Development and 45 high-income and 95 non-high income countries spanning 2003 2012, we empirically investigate how bilateral greenfield investment responds to common membership in Regional Trade Agreements. Unlike the Regional Trade Agreement-trade nexus, there have been very few studies that investigate the effects of Regional Trade Agreements on bilateral Foreign Direct Investment flows. Our chosen model specifications include Poisson Pseudo-Maximum-Likelihood estimator with bilateral and country-time fixed effects. We find that common membership in Regional Trade Agreements discourages greenfield investment in Organization for Economic Co-operation and Development-high income country pairs whereas they promote nonhigh income country pairs. We also find that lead and lagged Regional Trade Agreement common membership discourages greenfield investment in Organization for Economic Co-operation and Development-high-income pairs while it encourages non-high-income country pairs.
\end{abstract}

\footnotetext{
* Corresponding Author: Hyun-Hoon Lee; Department of International Trade and Business, Kangwon National University, Chuncheon, 200-701, Republic of Korea; E-mail: hhlee@kangwon.ac.kr.

Co-Author: Badassa Wolteji Chala; Department of International Trade and Business, Kangwon National University, Chuncheon, 200-701, Republic of Korea; E-mail: badassa@kangwon.ac.kr.
} presented at the Korea and the World Economy Conference, Beijing, August 2015. 
JEL Classifications: F21, F23, G15, G32, G34

Keywords: Bilateral Greenfield Investment, Regional Trade Agreements, Endogeneity, Gravity

\section{Introduction}

Since the conclusion of the General Agreements on Tariffs and Trade (GATT)'s Uruguay Round in 1993, many countries have opted for Regional Trade Agreements $\left(\right.$ RTAs $\left.^{1}\right)$. Subsequently, the number of effective RTAs notified to World Trade Organization (WTO) has accelerated from 20 in 1990 to 231 in 2012. ${ }^{2}$ This has inspired many studies to examine the effects of RTA membership on international trade. For example, Baier and Bergstrand (2002, 2007), Baier et al. (2014), Egger et al. (2008), and Eicher et al. (2012) have investigated whether the proliferation of RTAs have met their objectives in terms of promoting trade flows. Whereas Baier and Bergstrand (2002, 2007) and Baier et al. (2014) find that Free Trade Agreements (FTAs) promote international trade, Eicher et al. (2012) document the trade creating and diverting effects of FTAs.

While RTAs primarily influence international trade, it is also expected that they would affect Foreign Direct Investment (FDI). When a country forms an RTA with other countries, this may cause not only firms from non-member countries to establish subsidiaries in the RTA-member country, i.e., third-country effect, but also firms from a home country within the RTA block to move their factories to another RTA-member host country, i.e., bilateral effect. Unlike the RTA-trade nexus, there have been very few studies that investigate the effects of RTAs on bilateral FDI flows, as will be discussed subsequently.

\footnotetext{
'RTAs encompass Preferential Trade Arrangements (PTAs), Free Trade Agreements (FTAs), Custom Union (CU), Common Market (CM), and Economic Union (EU). Whereas PTAs lower barriers to trade among members than on trade with non-members, FTAs remove all trade barriers among members though each member retains its own trade policies towards non-members. In addition to removing all trade barriers among members, CUM harmonizes members' external trade policies. If members decide to form a CM, they need to additionally allow free movement of goods and services. Formation of an EU demands members to harmonize their fiscal and monetary policies besides implementing policy reforms required by PTAs, FTAs, CUM, and CM.

2 Over 100 other agreements were believed to be in force but not yet notified to the WTO: For more information refer to: https://www. wto.org/english/news_e/news12_e/trdev_28nov12_e.htm. See also RTAs Facts and Figures available at https://www.wto.org/english/ tratop_e/region_e/regfac_e.htm.
} 
Cognizant of the limitations on studies pertaining to RTA-FDI relationships, during the 2013 United Nations Conference on Trade and Development (UNCTAD) expert meeting on RTAs and FDI, many delegates called for more studies on the topic. The delegates have emphasized the urgency of policy recommendations that could further strengthen mutual relationships among RTAs and FDI (UNCTAD 2013). The call indicates that the subject is high on agenda not only for academic exercises but also for policy making. Therefore, we contribute to the literature on the RTA-FDI nexus using a newly available greenfield international investment dataset.

There are two modes of FDI, greenfield investment and cross-border M\&A. While greenfield investment involves construction of new facilities, cross-border M\&A is a combination of two or more companies that aim to attain strategic financial objective. In other words, greenfield investment involves setting up a new company from the ground up in a foreign country while cross-border M\&A does not. In the present study, we particularly focus on greenfield investment since it is often accompanied by inflows of managerial skills, technological know-how, and creation of job opportunities. Such a study would, therefore, be helpful for policy makers who are usually interested to know how joining and/or forming RTAs with other countries would influence greenfield investment flows to their countries.

By using bilateral data between 25 major Organization for Economic Co-operation and Development (OECD) and $140^{3}$ high-income and non-high income individual countries for the period 2003 2012 with 3 years interval, we investigate how greenfield investment responds to common membership in RTAs. Specifically, we investigate how greenfield investment response differently to RTAs' common membership for high income from non-high income host countries. Our model specification combines both bilateral and country-time fixed effects to account for any time varying observable and unobservable effects that may have confounding effects with RTAs in influencing bilateral greenfield investment flows. We rely on Pseudo Poisson Maximum Likelihood (PPML) estimator as it has a number of merits. ${ }^{4} \mathrm{We}$ find that common membership in RTAs discourages bilateral greenfield investment from OECD to high income countries but promotes investment to non-high income countries. We also find lead as well as lagged effects of RTAs' common membership on bilateral greenfield investment in both high-income and non-high income host countries.

\footnotetext{
${ }^{3}$ We include 45 high income OECD and non-OECD and 95 non-high income countries as host countries. For empirical purpose, we construct 3 years interval, namely, 2003, 2006, 2009, and 2012.

${ }^{4}$ Refer to Section IV for discussion on the merits of the PPML estimator.
} 
Intuitively, there are a number of pathways through which RTAs could influence FDI flows. First, in addition to trade in goods, some RTAs explicitly include issues related to FDI; intellectual property rights protections, and trade in services. For example, North America Free Trade Agreement (NAFTA) includes rules such as lifting restrictions on FDI and dispute settlement (Marszk 2014). Secondly, RTAs may incorporate measures that specifically promote FDI, such as preferential tax treatment (Te Velde and Bezemer 2006).

There are also a number of ways through which RTAs would specifically influence greenfield investments. RTAs may promote greenfield investment by reducing fixed investment costs. Moreover, reduction in trade cost following RTAs would make intra-firm trade less costly thereby encouraging greenfield investment. This intuition follows recent developments in production fragmentation, ${ }^{5}$ which involves back and forth oscillation of intermediate goods between home and host countries. Furthermore, since recent RTAs often incorporate intellectual property rights protection, investors are confident to transfer their technologies to host countries along with their investments. ${ }^{6}$

\section{Literature Review}

From theoretical perspectives, there have been some studies that investigate the effects of proliferation of RTAs on FDI. These theoretical studies can be categorized into two. While some of the theoretical papers examine third country effects, others deal with bilateral impacts. Theoretical studies such as Motta and Norman (1996), Raff (2004), Ito (2013), and Cook and Wilson (2013) focus on exploring the third country effects of RTAs on FDI. For example, using three-country, three firms game theoretic model in an oligopolistic market structure, Motta and Norman (1996) show that intra-regional market accessibility following the formation of RTAs stimulate outside firms to invest in the integrating regional block. Similarly, Ito (2013) shows that a decrease in either intra-regional or extra-regional trade costs induce firms to choose export platform FDI. Using a three-country model, Raff (2004) shows that FTAs may lead to FDI creation and

\footnotetext{
${ }^{5}$ Discussion on recent surge in intra-firm trade is discussed in Irarrazabal et al. (2013).

${ }^{6}$ For example, Nagano (2013) finds that a firm tends to choose greenfield investment when host country adequately enforces intellectual property rights laws.
} 
consolidation, but typically not to FDI destruction. ${ }^{7}$ Using Raff's model set up, Cook and Wilson (2013), however, dispute the final claim arguing that FDI destruction is possible.

The second group of theoretical papers incorporates the bilateral effects of RTAs on FDI. For example, Ekholm et al. (2007) develop a three-region model with two identical large, high-cost countries and a small, low-cost country. The authors show that the formation of FTAs between a big, high-cost country and a small, low-cost country increases export platform FDI in the low cost country by both insider and outsider firms. In other words, the authors show that FTAs could have bilateral effects on FDI flows.

Based on an oligopoly market structure, Kim (2009) theoretically shows that the formation of an FTA between a home and a host country decreases an incentive to switch to greenfield investment from exporting. The author argues that the formation of FTA between home and host countries eliminates the tariff-jumping advantage of greenfield investment, thereby discouraging greenfield investment. Similarly, Tekin-Koru (2011) shows that falling trade costs may discourage greenfield investment, reinforcing the theoretical prediction put forward by Kim (2009).

From empirical perspectives, there are also some studies that investigate the impacts of RTAs on FDI. Similar to theoretical studies, empirical studies can be grouped into two. While the first group of empirical studies examines the third country effects of RTAs on FDI, the second group of literature focuses on the bilateral effects of RTAs on bilateral FDI. For example, Chen (2009) finds that the formation of Preferential Trade Agreements (PTAs) leads to an increase in FDI by outsider multinationals, which involves third country effect. However, the author claims that not all integrating countries will experience equal FDI inflows; rather, low cost countries may receive more inflows of FDI at the expense of higher cost ones. This is because Multinational Enterprises (MNEs) may concentrate their production facilities in a low cost country and serve others through exports to achieve economic scale.

Likewise, focusing on the European Union (EU), NAFTA, Southern Common (MERCOSUR), and Association of Southeast Asian Nations (ASEAN), Kreinin and Plummer (2008) find that RTAs lead to investment diversion in a significant number of cases. This is particularly the case in developing countries that are not members of a regional grouping in which at least one developed country is a member.

FDI creation occurs when a firm locates in a low cost country where there is an FTA but not in the absence of the FTA. FDI consolidation happens if the firm locates in the low and the high cost counties in the absence of FTA but locates only in the low cost country in the presence of FTA and serves the high cost country via export. FDI destruction refers to the case in which an MNE shutting down its foreign affiliate inside a free trade area. 
In addition, there have been few empirical studies that examine the effects of RTAs on bilateral FDI. ${ }^{8}$ Using bilateral outward FDI stock from 20 OECD countries to 60 host countries, Yeyati et al. (2003) investigate the impact of RTAs on the location of FDI for the period 1982 1999. By employing panel data analysis with country pair fixed effect, they find that common membership in an RTA with home country increases FDI stock from that source by $27 \%$. The authors argue that host countries that are more open and whose factor proportions differ significantly from those in the home countries most likely attract a vertical type of FDI. The authors further emphasize that only member host countries that provide a more attractive business environment are likely to attract more FDI. ${ }^{9}$ Although the authors detect the possibility of the FDI diverting effect of RTAs, they argue that the agreements, on average, attract FDI.

Using bilateral outward FDI between 24 home and 28 host European countries, Baltagi et al. (2008) document the relocation of FDI from Western European host countries to Western and Eastern European host countries following European RTAs. The authors conclude that trade regionalism for a given home country exerts positive effects on FDI in Eastern European host countries where vertical FDI prevails, and negative effects on Western European host countries where horizontal FDI prevails.

Based on knowledge-capital model, Jang (2011) finds that the effect of bilateral FTAs on bilateral outward FDI stock varies by the home and host countries' skill difference. The author finds that while bilateral FTAs discourage bilateral FDI stock in OECD-OECD country pairs where skill difference is small and horizontal FDI prevails, bilateral FTAs encourage bilateral FDI stock in OECD-non-OECD country pairs where skill difference is large and vertical FDI prevails.

Using bilateral FDI flows between 28 home and 83 host countries for the period 1978 2004, Berger et al. (2013) find that FDI responds positively to RTAs only if the RTAs offer liberal admission rules. The authors argue that RTAs without strong investment provision may even discourage FDI.

In this paper we contribute to the effort of understanding the impacts of RTAs on bilateral FDI flows as follows.

First, while most studies use net FDI stocks or flows based on the balance of payments, we use greenfield investment flow data which are acquired from fDi Intelligence (Financial Times Ltd.). There are several advantages of using the greenfield

\footnotetext{
${ }^{8}$ Since the current paper focuses on bilateral effects of common membership in RTAs on greenfield investment, our literature review mostly confined to papers that particularly address related subject.

${ }^{9}$ Blomström and Kokko (1997) also draw similar conclusions.
} 
investment flow data. Because we are concerned with multinationals' response to new RTAs' common membership, FDI flow data are preferable to FDI stocks. However, the net FDI flow data based on the balance of payments often reveal negative values, which often pose a challenge for estimation. FDI data based on the balance of payments are comprised of both greenfield FDI and cross-border M\&As which may respond differently to RTAs' membership.

Second, our estimation is based on a gravity model specification that emphasizes the role of multilateral resistance terms and effectively accounts for the endogeneity of RTAs, which are overlooked by related studies. Furthermore, we handle zeros with the PPML estimator proposed by Silva and Tenreyro (2006). Third, we assess not only the contemporaneous effects of RTA, but also the lead and lagged effects of RTAs since these aspects of the RTA-FDI nexus have been ignored in the literature.

The rest of the paper is organized as follows. While Section III is devoted to data and descriptive statistics, Section IV explains the details of our estimation strategy. Section $\mathrm{V}$ presents empirical results along with discussions. Finally, Section VI concludes the paper.

\section{Data and Descriptive Statistics}

Greenfield investment data are from Financial Times Ltd. fDi Market database. The study covers 25 major OECD home countries and $140^{10}$ OECD and non-OECD individual economies (45 high-income and 95 non-high-income countries). Data on the total population and GDP per capita are from the World Bank's Development Indicators. Our bilateral investment treaties are from the UNCTAD homepage. RTAs' dummy variable is compiled from the WTO-RTA database. We have included only PTAs, FTAs, CU, CM, and EU. Partial agreements are excluded.

Our dependent variables are both value and number of greenfield investment projects. Specifically, the present study covers on average $74.6 \%$ of the global greenfield investment value with the highest being in 2004 (80.7\%) and the least being in 2012 $(70.6 \%)$. In terms of the number of greenfield investment projects, the study covers on

\footnotetext{
${ }^{10}$ Host countries are included into the study based on the availability of data on key variables.
} 
average $82.5 \%$ of the global number of greenfield investment projects with the highest being in $2004(85.3 \%)$ and the least contribution being in 2012 (80.5\%). These numbers demonstrate that the 25 major OECD countries take the leading role in global greenfield investment, which justifies their inclusion as home countries. As Figure 1 and Figure 2 clearly demonstrate, the characteristics of greenfield investment from the sample home countries resemble that of greenfield investment from the world as a whole. Therefore, inferring global greenfield investment response to RTAs' common membership based on the sample countries could yield fairly representative results.

Figure 1. Value of greenfield investment flows

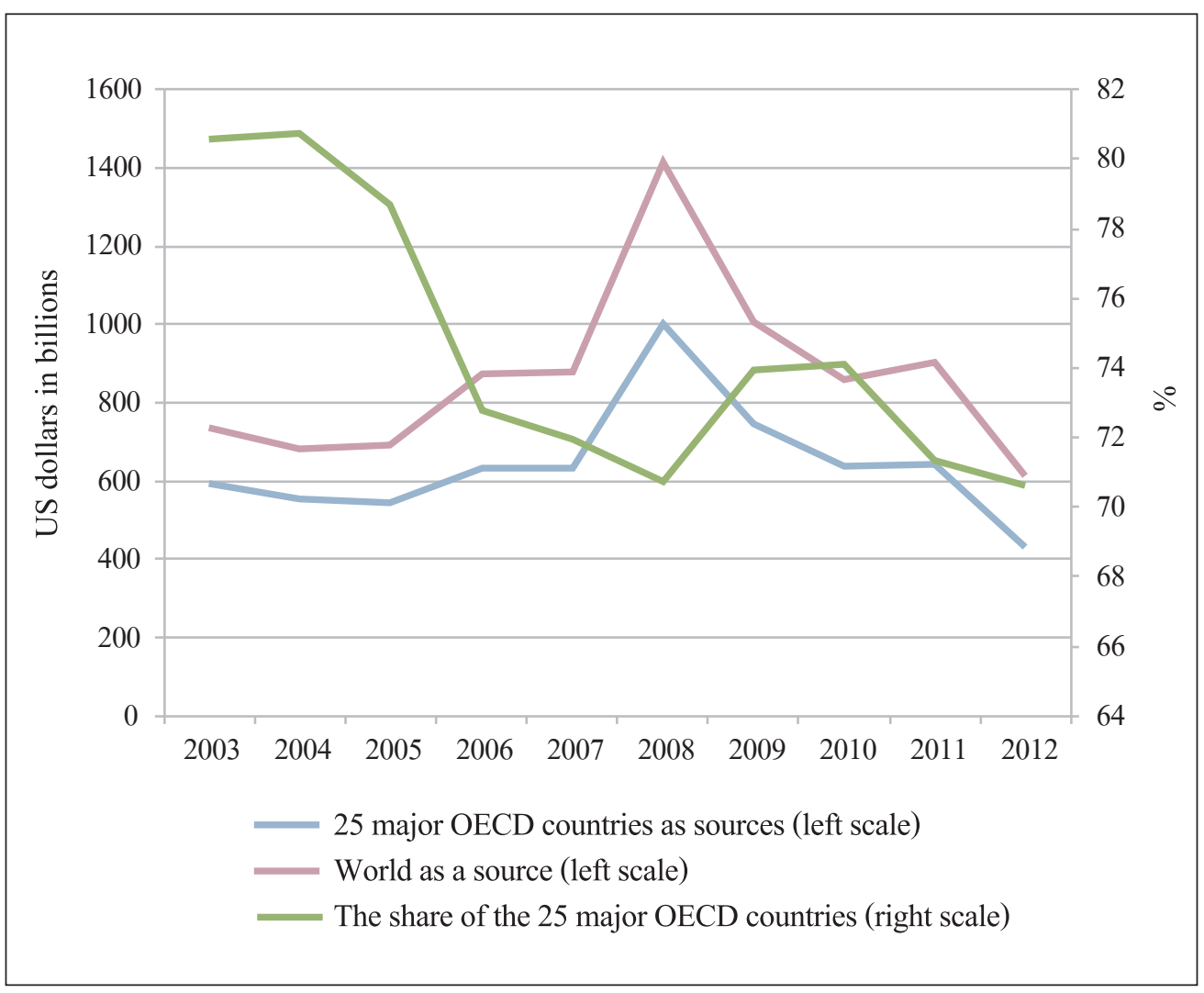

(Note) Data is estimated amounts of capital investment.

(Source) Authors' calculation based on data accessed from UNCTAD homepage. 


\section{Figure 2. Number of greenfield investment projects}

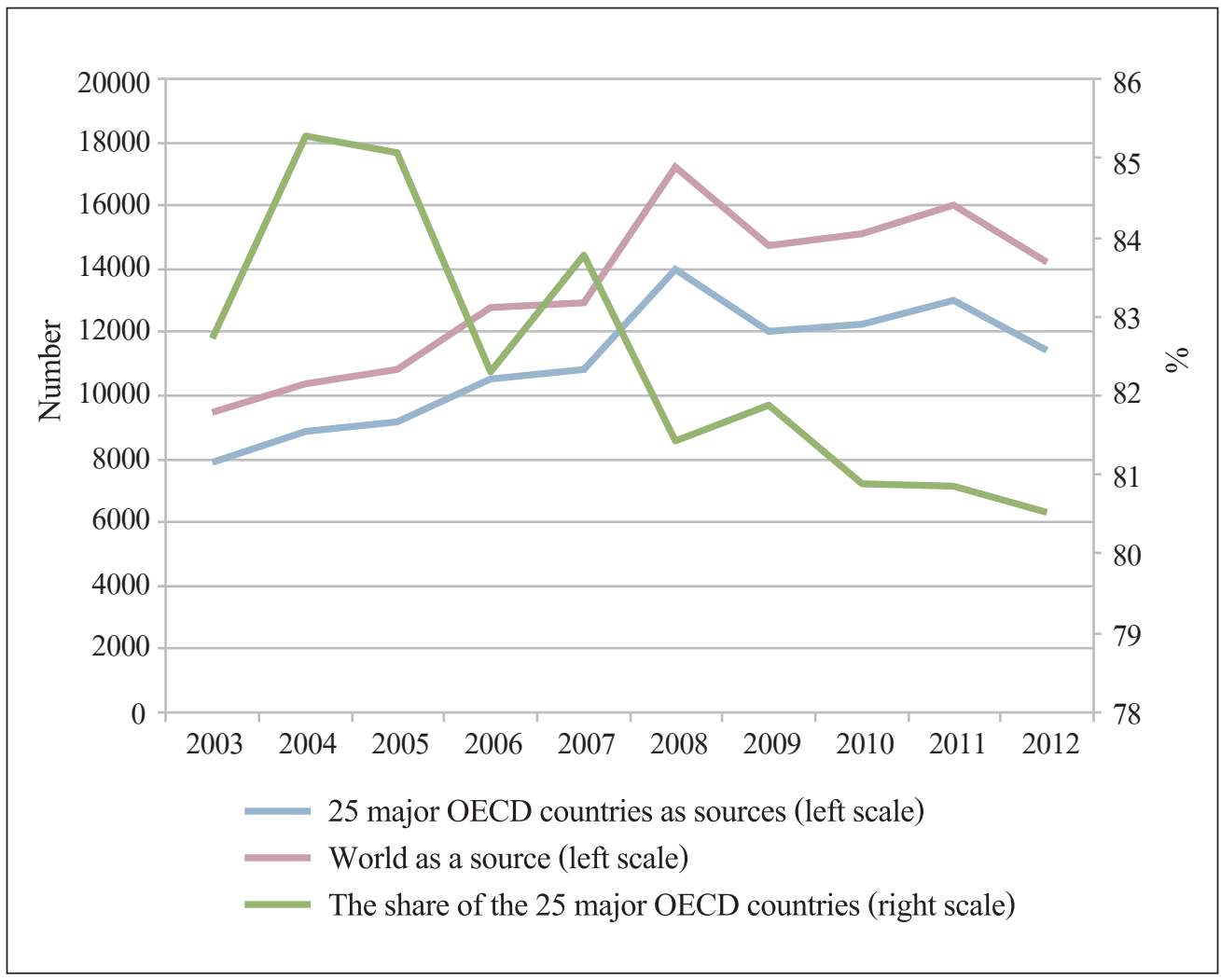

(Note) Data is estimated amounts of capital investment.

(Source) Authors' calculation based on data accessed from UNCTAD homepage.

The two figures also show that both greenfield investment values and number of investment projects varied considerably over the time period considered. During the same period, the number of RTAs has also been increasing as depicted in Figure 3. This has invited us to empirically investigate the impact of the proliferation of RTAs on greenfield investment bilateral flows. However, since there are numerous confounding factors, it is essential to account for home and host countries' individual and bilateral characteristics, along with global business cycle to single out the impact of RTAs. Consequently, we shall undertake detailed econometric investigations. 
Figure 3. Trends in Regional trade agreements

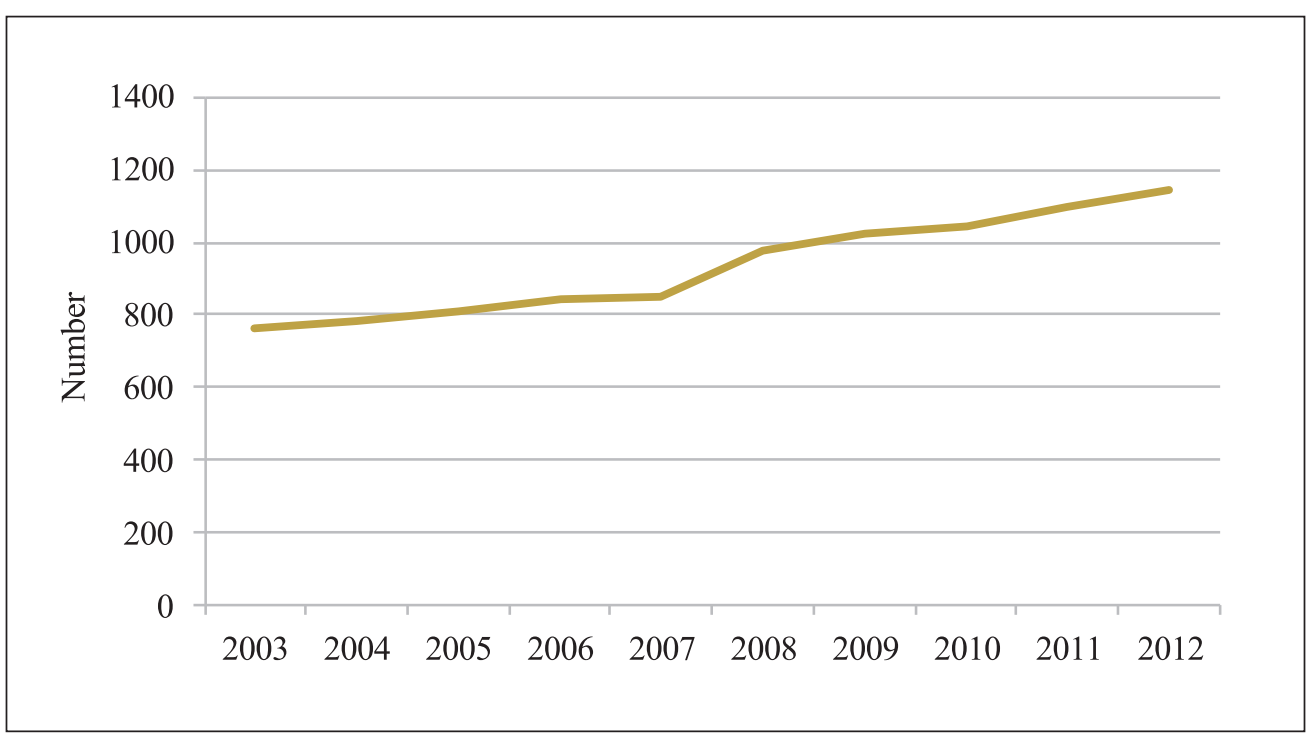

(Note) The number RTAs are physical counts and are cumulative.

(Source) Authors' compilation based on WTO database.

\section{Estimation Strategy}

\section{A. Model specification}

For more than five decades, gravity-like mode has been widely used in explaining bilateral trade flows. On account of its flexibility, some authors such as Bergstrand and Egger (2007) and Kleinert and Toubal (2010) have recently extended the model to explain cross-border FDI flows. In particular, Kleinert and Toubal (2010) derive gravity equations for bilateral FDI flows from various theoretical underpinnings. ${ }^{11}$ By incorporating proximity-concentration hypothesis, the authors assume that firms incur the distance costs of an iceberg type. This implies that only a fraction of shipped intermediate good arrives at its destination with the rest being lost along the way. Accordingly, the authors derive an expression given by:

\footnotetext{
${ }^{11}$ Specifically, symmetric firm proximity-concentration and factor proportion theories.
} 


$$
n_{i} p_{i j} x_{i j}=n_{i} p_{i i}{ }^{1-\sigma} \tau_{i j}{ }^{(1-\sigma)(1-\epsilon)}(1-\mu) Y_{j} p_{j}^{\sigma-1}
$$

Here, $n_{i} p_{i j} x_{i j}, n_{i} p_{i i}{ }^{1-\sigma}$, and $(1-\mu) Y_{j} p_{j}^{\sigma-1}$ denote bilateral affiliates' sales, home country's supply capacity, and host country's market capacity, respectively. The authors further assume that distance or transaction $\operatorname{costs}\left(\tau_{i j}\right)$ are an increasing function of bilateral geographic distance; that is, $\tau_{i j}=\tau D_{i j}^{\eta 1}$ where $\tau$ is unit distance cost such that $\tau>0$. Thus, the above equation can be reduced to $A S_{i j}=S_{i}\left(\tau D_{i j}^{\eta 1}\right)^{(1-\sigma)(1-\epsilon)} M_{j}$, where $A S_{i j}$ is bilateral foreign affiliates' sale and $S_{i}\left(M_{j}\right)$ is home (host) countries' supply (market) capacity. The log-linearized form of the model after introducing time dimension becomes:

$$
\ln \left(A S_{i j t}\right)=\beta_{0}+\beta_{1} \ln S_{i t}+\beta_{2} \ln M_{j t}+\beta_{3} \ln \left(D_{i j}\right)+\varepsilon_{i j t}
$$

Where $\beta_{0}=(1-\sigma)(1-\epsilon)(\ln \tau) ; \beta_{3}=(1-\sigma)(1-\epsilon)\left(\eta_{1}\right)$

Here, $A S_{i j t}$ proxies $F D I_{i j t}{ }^{12}$ flow from country $i$ to country $j$ in any year $t . S_{i t}$ and $M_{j t}$ respectively represent economic masses of countries $i$ and $j$ in any year $t, D_{i j}$ represents physical distance between the two countries, $\beta$ 's are parameters to be estimated, and $\varepsilon_{i j t}$ is an error term. The distance parameter, $\beta_{3}<0$, since $\sigma>1$. The above expression is very similar to the common intuitive gravity model often augmented in investigating crossborder trade and finance flows.

Existing data show that many country pairs involve zero investment flows. For instance, for the 3 years interval we have constructed 2003, 2006, 2009, and 2012, the proportion of zero greenfield investment flows form 25 OECD countries to high income and non-high income countries constitutes $16 \%$ and 52\%, respectively. Ignoring this fact would lead to misleading results. Therefore, model specification that performs very well in the presence of a larger number of absolute zero would be an ideal candidate.

Model specification like the one shown in Equation (2) does not incorporate absolute zero flows since the natural logarithm of zero is undefined and is consequently dropped. As a result, such a log-linear model specification has recently become less popular. Moreover, Silva and Tenreyro (2006) argue that estimating a log-linearized equation by Ordinary Least Square (OLS) results in bias. Following Jensen's inequality, the authors

\footnotetext{
${ }^{12}$ Studies such as Carr et al. (2001) and Bergstrand and Egger (2007) use sales of foreign affiliates as dependent variables in investigating FDI determinants.
} 
argue that $E\left[\ln \left(\varepsilon_{i j t}\right)\right] \neq \ln E\left[\left(\varepsilon_{i j t}\right)\right]$. The conditional distributions of the dependent variable will be changed and estimation by OLS would produce misleading estimates. Thus, the $t$-values for the estimated coefficients cannot be trusted. They have proposed instead a PPML estimator which takes the following general form:

$$
y_{i}=\exp \left[X_{i} \beta\right] \varepsilon_{i}
$$

In this equation, $y_{i}$ is a dependent variable such that $y_{i} \geq 0$ and $E\left[\varepsilon_{i} \mid x_{i}\right]$. In addition, the authors describe estimating $\beta$ by OLS as inappropriate. They argue that even when the dependent variable is positive, the expected value of the log-linear error term often depends on the explanatory variables producing inconsistent estimates. Given the appropriateness of the PPML estimator for the nature of our data and its increasing recognition in the literature, we rely on this estimator in the present paper.

Following the above discussions, PPML estimator in the context of the current study would take the following form:

$$
\begin{gathered}
F D I_{i j t}=\beta_{0}+\beta_{1} \ln \left(P O P_{i t}\right)+\beta_{2} \ln \left(P O P_{j t}\right)+\beta_{3} \ln \left(G D P p c_{i t}\right)+\beta_{4} \ln \left(G D P p c_{j t}\right) \\
+\beta_{5} R T A_{i j t}+6 B I T_{i j t}+\psi_{j t}+\psi_{t}+\varepsilon_{i j t}
\end{gathered}
$$

Where $F D I_{i j t}$ represents greenfield investment (values and number of projects) flows from country $i$ to country $j$ in any period $t$; $P O P_{i t}\left(P O P_{j t}\right)$ denotes home (host) total population to proxy economic masses ${ }^{13}$; and $G D P p c_{i t}\left(G D P p c_{j t}\right)$ represents home (host) GDP per capita. $R T A_{i j t}$ is an effective RTA membership to which both home and host countries belong while $B I T_{i j t}$ is an effective bilateral investment treaty between home and host countries. $R T A_{i j t}$ and $B I T_{i j t}$ enter the model with a value of 1 whenever they are effective, and 0 otherwise. We also include time unvarying ${ }^{14}$ fixed effects $\left(\psi_{j t}\right)$ to capture all time fixed bilateral effects and period fixed effects $\left(\psi_{t}\right)$ to control the global business cycle in the form of booms and recessions. $\varepsilon_{i j t}$ is an error term such that $\varepsilon_{i j t} \sim N\left(0, \sigma^{2}\right)$.

\footnotetext{
${ }^{13}$ We use total population instead of GDP to proxy economic masses to avoid collinearity between GDP and GDP per capita.

${ }^{14}$ Includes common language, contiguity, colonial relationships, bilateral physical distance and other unobserved time unvarying bilateral effects. $R T A_{i j t}$ and $B I T_{i j t}$ variables which were presented as components of distance costs in Equation (2) are now presented separately since they vary over time and can be influenced by policies.
} 


\section{B. Endogeneity issues}

In an econometric modeling, the potential endogeneity of an independent variable occurs whenever the variable is correlated with an error term. This violates one of the basic assumptions of OLS resulting in biased and inconsistent estimates. In international trade literature, it is well-recognized that trade policies such as RTAs are not exogenous. For example, based on a sample of OECD country-pairs, Egger et al. (2008) find a strong effect of endogenous RTAs on intra-industry trade. The sources of endogeneity bias can be due to omitted variables (selection bias), simultaneity (reverse causality), and/or measurement errors (Wooldridge 2002). However, Baier and Berstrand (2007) argue that omitted variable (selection bias) is the main cause of endogeneity pertaining to RTAs. This is because the process of forming RTAs often begins with discussions between trading partners which likely leads to self-selection. They further argue that self-selection into RTAs may be for reasons that are unobservable yet correlated with the level of (trade) bilateral flows leading to endogeneity bias.

In the context of the present study, $E(F D I \mid X, \psi)$ is conditional expectation of our interest, which can be written as a function linear in parameters and additive in $\psi . X$ and $\psi$ denote home, host, and bilateral characteristics that may influence bilateral greenfield investment flows. ${ }^{15}$ If $\psi$ is unobservable, we can only estimate $E(F D I \mid X)$ which does not have any particular relationship to $E(F D I \mid X, \psi)$ when $\operatorname{corr}(X, \psi) \neq 0$. According to Wooldridge (2002), one way to handle such a case is to represent the unobservable factor, $\psi$, with the error term. Since $X$ and $\psi$ are correlated, $X$ is now endogenous. The correlation of explanatory variable with an observable is often due to self-selection, which is most likely to happen in the case of RTAs.

To account for the endogeneity bias related to FTAs, previous studies applied instrumental-variable and panel data econometric estimation techniques. For example, Baier and Berstrand (2002) and Magee (2003) have applied the instrumental variable method to account for endogeneity bias to estimate the effect of FTAs on bilateral trade flows. Earlier studies such as Trefle (1993) and Lee and Swagel (1997) also applied instrumental variable technique to account for such a bias. The authors argue that estimates of trade policy reforms on imports are underestimated substantially due to endogeneity bias. In the context of FDI, Bae and Jang (2013) address the endogeneity of FTAs with Arellano-Bond estimation that incorporates the application of instrumental variable.

\footnotetext{
${ }^{15}$ Note that subscripts are omitted to keep the notations simpler.
} 
Recently, Baier and Berstrand (2007), however, strongly argue that endogeneity bias can be effectively accounted for by using a panel data estimation technique. They claim that instrumental variable technique is often compromised due to lack of appropriate instruments. They, therefore, conclude that the effect of FTAs on bilateral (trade) flows can be best estimated by theoretically motivated gravity equation using panel data with bilateral and country-time fixed effects. Other authors such as Anderson and Yotov (2011) and Egger et al. (2008) also argue in favor of panel data technique to account for endogeneity bias in the context of gravity modeling.

In this paper, we follow the Baier and Berstrand (2007) methodology to estimate the effects of RTAs on greenfield investment flows. Since the usual gravity covariates ${ }^{16}$ exogenous, only policy variables, namely, RTAs and Bilateral Investment Treaties (BITs), are potentially endogenous. Thus, by including home-host country pair fixed effects, we control for any time unvarying fixed effects. Moreover, we include country-time fixed effects to effectively account for any time varying observable and unobservable effects that may also influence the bilateral flows of greenfield investment. By doing so, we can effectively isolate the effects of all variables that have confounding effects with RTAs in influencing bilateral greenfield investment flows.

Therefore, controlling for time unvarying bilateral and time fixed effects alone will not totally address endogeneity bias associated with RTAs. Following Baier and Bergstrand (2007) and Baier et al. (2014) methodology, we incorporate countrytime fixed effects along with bilateral fixed effects. This specification accounts for any possible endogeneity bias associated with RTAs. Thus, our final preferred model specification would take the following form:

$$
F D I_{i j t}=\beta_{0}+\beta_{1} R T A_{i j t}+\beta_{2} B I T_{i j t}+\psi_{j t}+\psi_{i j}+\varepsilon_{i j t}
$$

Here, $\psi_{i t}$ and $\psi_{j t}$ are country-time fixed effects for home and host countries, respectively. These fixed effects capture all time varying home and host countries' characteristics (both observable and unobservable) that may attract or deter bilateral greenfield investment flows. Particularly, the time varying yet unobserved fixed effects are often omitted in the traditional gravity model leading to omitted variable bias. Hence, incorporating country-time fixed effects would control for omitted variable bias, which

\footnotetext{
${ }^{16}$ Include bilateral distance, contiguity, colonial ties, and common language. In our model set-up, these variables are captured by bilateral fixed effects.
} 
is the main source of endogeneity bias. The time varying fixed effects include the usual gravity covariates such as home and host countries' economic masses; that is, population sizes, GDP per capita, and home and host countries' multilateral resistance terms as discussed in Anderson and Wincoop (2003).

\section{Lead and lags of Regional Trade Agreements}

In addition to omitted variable bias, reverse causality (simultaneity) may also contribute to the endogeneity of RTAs. Following Baier and Bergstrand (2007) methodology, we incorporate the future (lead) values of policy variables that are potentially endogenous; namely, RTAs and BITs. MNEs may increase their investment activities in anticipation of RTAs as they could respond to RTAs earlier than the actual enforcement of the RTAs. During negotiations or after signing the RTAs, MNEs may increase or decrease their greenfield investment activities to the RTA partner country. ${ }^{17}$ To capture these feedback effects of RTA and the possible change in the investment behavior of the MNEs, we introduce one period (3 years) future (lead) RTAs into our model. Thus, our model is modified as:

$$
F D I_{i j t}=\beta_{0}+\beta_{1} R T A_{i j t}+\beta_{2} R T A_{i j(t+1)}+\beta_{3} B I T_{i j t}+\beta_{4} B I T_{i j(t+1)}+\psi_{i t}+\psi_{j t}+\psi_{i j}+\varepsilon_{i j t}
$$

Where $R T A_{i j(t+1)}$ and $B I T_{i j(t+1)}$ respectively denote one period (3 years) future (lead) RTAs and BIT between the two country pairs for any period $t$.

Furthermore, common membership in RTAs may also have a lag effect since it often takes time for greenfield investments to respond to such policies. This is likely to happen since greenfield investment requires the construction of new facilities. To account for this, we introduce one period (3 years) lagged RTA denoted by $R T A_{i j(t-1)}$. For this purpose, our preferred specification becomes:

$$
F D I_{i j t}=\beta_{0}+\beta_{1} R T A_{i j t}+\beta_{2} R T A_{i j(t-1)}+\beta_{3} B I T_{i j t}+\beta_{4} B I T_{i j(t-1)}+\psi_{i t}+\psi_{j t}+\psi_{i j}+\varepsilon_{i j t}
$$

Here, $R T A_{i j(t-1)}$ and $B I T_{i j(t-1)}$ respectively stand for one period (3 years) lagged RTAs

\footnotetext{
${ }^{17}$ The actual enforcement of RTAs may take time since partner countries should get the agreements approved by their respective legislative body/or parliament.
} 
and BITs. The purpose of this specification is to investigate how greenfield investment values and number of projects react to RTAs after being implemented 3 years ago.

\section{Empirical Results}

\section{A. Contemporaneous effects of Regional Trade Agreements}

\section{Benchmark results}

In Table 1, we report results obtained from traditional model specification. This specification controls for bilateral, home and host countries', and time fixed effects. By controlling for bilateral fixed effects, we consider all time unvarying effects that may influence bilateral greenfield investment flows. By incorporating countries' fixed effects, we include unobserved home and host country fixed effects that may attract or deter bilateral greenfield investment flows. Furthermore, the inclusion of period fixed effect as covariate controls for global business cycle may influence bilateral greenfield investment flows. We proxy home and host countries' economic masses by their respective total populations and we include home and host countries' GDP per capita to account for MNE's efficiency, seeking motives and roles of productivities.

As reported in column 2 of Table 1, the number of bilateral greenfield investment project reacts negatively to common membership in RTAs in OECD-high income country pairs. Specifically, the response from the bilateral number of greenfield investment project to common membership in RTAs is $100 \times\left[\exp ^{(-0.241)}-1\right] \cong-21.4 \%$, or $21.4 \%$ decrease. Nevertheless, the response from bilateral greenfield investment value to common membership in RTAs is found to be statistically insignificant in these country pairs. This empirical result is similar to a finding by Jang (2011) who documents that bilateral FTAs discourage bilateral FDI stock in OECD-OECD country pairs. The author, however, has not made a distinction between response from the aggregate value and the number of projects. Moreover, no clear reference was made to greenfield investment.

In contrast to OECD-high income country pairs, bilateral greenfield investment value reacts positively to common membership in RTAs in OECD-non-high income country pairs, shown in column 3 of Table 1. Precisely, common membership in RTAs increases bilateral greenfield investment value from OECD to non-high income countries by 
$100 \times\left[\exp ^{0.360}-1\right] \cong 43.3 \%$. This result is close to an estimate obtained by Yeyati et al. (2003). By using panel data analysis based on 20 OECD home and 60 host countries with country pair fixed effects, the authors find that common membership in RTA with home country increases FDI stock from that source by 27\%. Similarly, Jang (2011) finds that bilateral FTAs promote bilateral FDI stock from OECD to non-OECD country pairs. Although our statistical results are quite similar to the findings of these papers, this paper differs from the previous studies in many ways as previously discussed.

Table 1. Contemporaneous Effects of RTAs on greenfield investment

(without fully controlling for endogeneity bias)

\begin{tabular}{|c|c|c|c|c|}
\hline & \multicolumn{2}{|c|}{ High Income } & \multicolumn{2}{|c|}{ Non-High Income } \\
\hline & Value & Count & Value & Count \\
\hline & $(1)$ & (2) & (1) & (2) \\
\hline$R T A(0,1)$ & $\begin{array}{c}0.021 \\
(0.443)\end{array}$ & $\begin{array}{c}-0.241 * \\
(0.145)\end{array}$ & $\begin{array}{c}0.360 * * \\
(0.162)\end{array}$ & $\begin{array}{c}0.100 \\
(0.099)\end{array}$ \\
\hline$B I T(0,1)$ & $\begin{array}{c}-0.552 \\
(1.119)\end{array}$ & $\begin{array}{c}-0.030 \\
(0.282)\end{array}$ & $\begin{array}{c}-0.058 \\
(0.168)\end{array}$ & $\begin{array}{l}0.182 * \\
(0.101)\end{array}$ \\
\hline Population-Home $^{\wedge}$ & $\begin{array}{l}7.412 * \\
(4.193)\end{array}$ & $\begin{array}{l}7.569 * \\
(4.194)\end{array}$ & $\begin{array}{c}-2.713^{*} \\
(1.609)\end{array}$ & $\begin{array}{c}0.966 \\
(1.639)\end{array}$ \\
\hline Population-Host $^{\wedge}$ & $\begin{array}{c}-0.264 \\
(0.372)\end{array}$ & $\begin{array}{c}0.055 \\
(0.420)\end{array}$ & $\begin{array}{c}-1.824^{*} \\
(0.993)\end{array}$ & $\begin{array}{c}3.137 * * * \\
(0.552)\end{array}$ \\
\hline GDP per capita-Home ${ }^{\wedge}$ & $\begin{array}{l}-0.816 \\
(1.022)\end{array}$ & $\begin{array}{l}-0.292 \\
(0.679)\end{array}$ & $\begin{array}{l}-0.272 \\
(0.398)\end{array}$ & $\begin{array}{c}0.281 \\
(0.238)\end{array}$ \\
\hline GDP per capita-Host $t^{\wedge}$ & $\begin{array}{c}-1.719 * * * \\
(0.513)\end{array}$ & $\begin{array}{c}-0.868 * \\
(0.498) \\
\end{array}$ & $\begin{array}{c}-0.690^{* *} \\
(0.272)\end{array}$ & $\begin{array}{c}-0.324 * * \\
(0.128) \\
\end{array}$ \\
\hline \multicolumn{5}{|l|}{ Fixed Effects } \\
\hline Country-Pair (ij) & Yes & Yes & Yes & Yes \\
\hline Home-Country $(i)$ & Yes & Yes & Yes & Yes \\
\hline Host-Country $(j)$ & Yes & Yes & Yes & Yes \\
\hline $\operatorname{Period}(t)$ & Yes & Yes & Yes & Yes \\
\hline Observations & 3,216 & 3,216 & 3,899 & 3,899 \\
\hline$R$-square & 0.741 & 0.838 & 0.808 & 0.922 \\
\hline
\end{tabular}

(Notes) (i) Country pair clustered standard errors are in parentheses.

(ii) $* * *$, and $* * *$ indicate that the variable is statistically significant at $10 \%, 5 \%$, and $1 \%$, respectively.

(iii) Count represents the number of greenfield investment projects. 
More importantly, we argue that such results are less reliable as the endogeneity of RTAs is most likely hidden in the unobserved yet time-varying home and host country characteristics. As widely discussed in Baier and Bergstrand (2007), specifications that control only for country pairs and country fixed effects may suffer from omitted variable bias and would understate the impact of RTAs.

\section{Results after controlling for omitted variable bias}

In Table 2, we incorporate country-time fixed effects to account for omitted variable and adjust for endogeneity RTAs. After adjusting for all types of heterogeneities, ${ }^{18}$ we obtain results that support the argument that omitted variable bias would underestimate the impact of RTAs in bilateral greenfield investment flows . ${ }^{19}$ For instance, the reaction from the number of greenfield investment projects to common membership in RTAs now becomes $100 \times\left[\exp ^{(-0.435)}-1\right] \cong-35.3 \%$ in OECD-high income country pairs; that is, a common membership in an RTA between an OECD and a high income host country would decrease the number of bilateral greenfield investment flows from that home to the host country by $35.3 \%$ (refer to column 2 of Table 2 ). Thus, omitted variable bias underestimates the impact of common membership in RTA on the number of bilateral greenfield investment projects by $14 \%$ in absolute value; i.e., $|-35.3 \%-(-21.4 \%)|=14 \%$. Moreover, the RTA variable now becomes statistically significant at 5\% instead of $10 \%$.

Similarly, in OECD-non-high income country pairs, the response from bilateral greenfield investment value to common membership in RTA becomes $100 \times\left[\exp ^{0.489}-1\right]$ $\cong 63.1 \%$ increase (refer to column 3 ). In this case, the impact of common membership in RTAs on bilateral greenfield investment value is underestimated by about $20 \%(63.1 \%$ $-43.3 \% \cong 20 \%$ ). Moreover, the RTA variable now becomes statistically significant at $1 \%$ instead of $5 \%$.

By comparing results reported in Table 1 and Table 2, we can see that omitted variable bias underestimates both the statistical significance and the magnitude of the RTA coefficients. These results support the finding by Baier and Bergstrand (2007) who document much stronger effects of FTAs on trade flows after accounting for endogeneity bias using a panel estimation technique. Similarly, Trefler (1993) and Lee and Swagel (1997) argue that estimates of trade policy reforms on imports are substantially underestimated due to endogeneity bias. Our results, therefore, show that

\footnotetext{
${ }^{18}$ Include observables and unobservable that could be time varying and/or time unvarying.

${ }^{19}$ For more explanation on this, see Baier and Bergstrand (2007, p. 78).
} 
omitted variable bias underestimates the impact of common membership in RTAs on the bilateral greenfield investment's number of projects in high-income countries and aggregate values in non-high income countries.

The negative response of greenfield investment value to common membership in RTAs in OECD-high income country pair reinforces the theoretical prediction presented in Kim (2009) and Tokin-Koru (2011). More specifically, the negative reaction from bilateral greenfield investment flows to common membership in RTAs in OECD-high income country pairs reinforces tariff-jumping FDI hypothesis. Per such hypothesis, a lower tariff will deter tariff-jumping (horizontal type of) FDI but encourage vertical FDI. Since, most FDI flowing from OECD to high income countries is horizontal type, ${ }^{20}$ our empirical finding is consistent with the theoretical prediction that MNEs now can alternatively serve the host countries via exports. This would lead to a reduction in bilateral greenfield investment.

The positive response of greenfield investment value to common membership in RTAs in OECD-non-high income country pairs is also intuitively appealing since RTAs would promote greenfield investment by lowering greenfield investment fixed cost. In addition, RTAs could also encourage greenfield investment by reducing the cost of transporting intermediate goods between headquarters and subsidiaries. This is in line with vertical FDI which involves both trade and FDI. Reduction and/or elimination of tariffs following common membership in RTAs would make intra-firm trade less costly and hence encourage MNEs to boost their greenfield investment in the host country.

\footnotetext{
${ }^{20}$ Refers to the case in which MNEs duplicate the same production activities in many countries. In other words, developed countries are both sources and destinations to most FDI. This in turn implies market access is more important than reduction in production costs as a motive for FDI.
} 
Table 2. Contemporaneous Effects of RTAs on greenfield investment with fully controlling for endogeneity Bias

\begin{tabular}{|l|c|c|c|c|}
\hline \multirow{2}{*}{} & \multicolumn{2}{|c|}{ High Income } & \multicolumn{2}{c|}{ Non-High Income } \\
\cline { 2 - 5 } & Value & Count & Value & Count \\
\cline { 2 - 5 } & $(1)$ & $(2)$ & $(1)$ & $(2)$ \\
\hline \multirow{2}{*}{ RTA $(0,1)$} & -0.597 & $-0.435^{* *}$ & $0.489 * * *$ & 0.084 \\
& $(0.380)$ & $(0.212)$ & $(0.182)$ & $(0.117)$ \\
\hline \multirow{2}{*}{ BIT $(0,1)$} & -0.751 & 0.125 & -0.147 & 0.098 \\
& $(0.545)$ & $(0.187)$ & $(0.155)$ & $(0.088)$ \\
\hline Fixed Effects & & & & \\
\hline Country-Pair $(i j)$ & Yes & Yes & Yes & Yes \\
\hline Home-Period $($ it $)$ & Yes & Yes & Yes & Yes \\
\hline Host-Period $(j t)$ & Yes & Yes & Yes & Yes \\
\hline Observations & 3,174 & 3,174 & 3,888 & 3,888 \\
\hline R-square & 0.958 & 0.979 & 0.935 & 0.977 \\
\hline
\end{tabular}

(Notes) (i) Country pair clustered standard errors are in parentheses.

(ii) $* * *$, and $* * *$ indicate that the variable is statistically significant at $10 \%, 5 \%$, and $1 \%$, respectively.

(iii) Count represents the number of greenfield investment projects.

\section{B. Contemporaneous and lead effects of Regional Trade Agreements}

Since greenfield investment involves the construction of new facilities, multinational companies may take action in anticipation of RTAs. In other words, RTAs may have a lead effect in addition to their contemporaneous effects. Although we expect RTAs to cause greenfield investment, it is also possible that the direction of causality could run in reverse direction; that is, country pairs which already experience bilateral greenfield investment flows may seek to join the same RTAs or launch new RTAs. To check for reverse causality, we impose strict exogeneity assumption by including the lead (future) RTA and estimating Equation (6).

For this purpose, we incorporate contemporaneous and lead RTAs at a time. After controlling for all sources of endogeneity bias by including bilateral and country-time fixed effects, we obtain consistent results reported in Tables 1 and 2; that is, common 
membership in RTAs discourages greenfield investment flows from OECD to high income countries but promotes investment to non-high income countries. Specifically, common membership in RTA decreases greenfield investment value from OECD to high-income countries by $58 \%$ or $100 \times\left[\exp ^{(-0.872)}-1\right] \cong-58 \%$ due to contemporaneous effect and by $72 \% 100 \times\left[\exp ^{(-1.256)}-1\right] \cong-72 \%$ due to future (lead) effect. This shows that RTAs affect bilateral greenfield investment value both via influencing MNEs' expectations and their current investment activities. However, only contemporaneous common membership in RTA matters for the number of bilateral greenfield investment projects. Common membership in RTA has $100 \times\left[\exp ^{(-0.577)}-1\right] \cong-44 \%$ contemporaneous effect on the number of bilateral greenfield investment projects in these country pairs.

Likewise, the effect of RTAs on greenfield investment in OECD-non-high income country pairs is consistent with the results reported in Tables 1 and 2. For example, the lead effect of common membership in RTAs cause the numbers of bilateral greenfield investment projects to increase by $47.3 \%$ or $58 \%$ or $100 \times\left[\exp ^{(0.387)}-1\right] \cong-47.3 \%$. Moreover, the contemporaneous effect of common membership in RTAs is positively associated with bilateral greenfield investment value. That is, RTAs increase the bilateral greenfield investment value by $70 \%$ or $100 \times\left[\exp ^{0.528}-1\right] \cong 70 \%$ in these country pairs. These results once again support findings by Baier and Bergstrand (2007) and Trefler (1993) and Lee and Swagel (1997), which conclude that the effects of FTAs on trade flows are underestimated because of endogeneity bias that mainly arises from omitted variable bias. In addition, these empirical results confirm that there exist feedback effects of RTAs; i.e., causality could run from RTAs to bilateral greenfield investment value for OECD-high income countries as shown in column 1 and the number of bilateral greenfield investment projects for non-high income countries as shown in column 4. Moreover, it supports our hypothesis that MNEs may increase or decrease their investment activities in the host countries in anticipation of RTAs. Thus, MNEs from OECD countries decrease the number of bilateral greenfield investment projects to high income countries while they increase the value of their bilateral investment to non-high income countries in expectation of future RTAs. 
Table 3. Contemporaneous and Lead Effects of RTAs on greenfield investment

(with fully controlling for endogeneity bias)

\begin{tabular}{|c|c|c|c|c|}
\hline & \multicolumn{2}{|c|}{ High Income } & \multicolumn{2}{|c|}{ Non-High Income } \\
\hline & Value & Count & Value & Count \\
\hline & (1) & (2) & (1) & (2) \\
\hline$R T A(0,1)$ & $\begin{array}{c}-0.872 * \\
(0.465)\end{array}$ & $\begin{array}{c}-0.577 * * \\
(0.225)\end{array}$ & $\begin{array}{c}0.528 * * \\
(0.220)\end{array}$ & $\begin{array}{l}-0.085 \\
(0.126)\end{array}$ \\
\hline$R T A_{t+1}(0,1)$ & $\begin{array}{c}-1.256^{* *} \\
(0.524)\end{array}$ & $\begin{array}{l}-0.138 \\
(0.309)\end{array}$ & $\begin{array}{c}0.237 \\
(0.235)\end{array}$ & $\begin{array}{c}0.387^{* * *} \\
(0.140)\end{array}$ \\
\hline$B I T(0,1)$ & $\begin{array}{l}-0.748 \\
(0.590)\end{array}$ & $\begin{array}{c}0.241 \\
(0.200)\end{array}$ & $\begin{array}{l}-0.151 \\
(0.185)\end{array}$ & $\begin{array}{c}0.054 \\
(0.094)\end{array}$ \\
\hline$B I T_{t+1}(0,1)$ & $\begin{array}{l}-1.051 \\
(0.914) \\
\end{array}$ & $\begin{array}{l}-0.551 \\
(0.366) \\
\end{array}$ & $\begin{array}{l}-0.220 \\
(0.206)\end{array}$ & $\begin{array}{c}-0.205^{*} \\
(0.106) \\
\end{array}$ \\
\hline Fixed Effects & & & & \\
\hline Country-Pair (ij) & Yes & Yes & Yes & Yes \\
\hline Home-Period (it) & Yes & Yes & Yes & Yes \\
\hline Host-Period (jt) & Yes & Yes & Yes & Yes \\
\hline Observations & 2,229 & 2,229 & 2,557 & 2,557 \\
\hline$R$-square & 0.939 & 0.950 & 0.945 & 0.986 \\
\hline
\end{tabular}

(Notes) (i) Country pair clustered standard errors are in parentheses.

(ii) $* * *$, and $* * *$ indicate that the variable is statistically significant at $10 \%, 5 \%$, and $1 \%$, respectively.

(iii) Count represents the number of greenfield investment projects.

\section{Contemporaneous and lag effects of Regional Trade Agreements}

As highlighted before, greenfield investment by its very nature involves the construction of new facilities. Thus, it often takes time for this kind of investment to respond to policy changes such as common membership in RTAs. By estimating Equation (7), we specifically examine how greenfield investment responds to lagged RTAs by controlling for the contemporaneous effects of RTAs.

In Table 4, we report the results obtained by incorporating contemporaneous and lagged effects of common membership in RTAs simultaneously. The overall results 
are quite similar to those reported in previous tables. For example, the overall effect of common membership in RTA on greenfield investment is negative in OECD-high income country pairs while it is positive in OECD-non-high income country pairs. In OECD-high income country pairs, a positive response from the number of bilateral greenfield investment projects to contemporaneous common membership in RTA is 34\% or $100 \times\left[\exp ^{0.298}-1\right] \cong 34 \%$ increase whereas the lagged effect is $-53 \%$ or $100 \times\left[\exp ^{(-0.746)}\right.$ $-1] \cong 53 \%$ decrease which can be seen in column 2 . The net effect of the common membership in RTA on number of greenfield investment projects is, therefore, 19\% decrease.

Table 4 also confirms the positive response of greenfield investment to RTA common membership in OECD-non-high income country pairs. Specifically, the response from bilateral greenfield investment value to 3 years lag in common membership in RTA is $100 \times\left[\exp ^{0.449}-1\right] \cong 57 \%$ or $57 \%$ increase. This means that MNEs increase their bilateral greenfield investment value in non-high income host countries by $57 \%$ in three years time after the implementation of the RTAs. Consistent with results reported in previous tables, the contemporaneous effect of RTA on the value of bilateral greenfield investment remains positive and statistically significant; that is, $100 \times\left[\exp ^{0.421}-1\right] \cong$ $52 \%$ or $52 \%$ increase. Thus, the 3 years lagged RTA affect the number of greenfield investment projects in high-income countries (negatively) and the value of greenfield investments in non-high income countries (positively). 
Table 4. Contemporaneous and Lag Effects of RTAs on greenfield investment

(with fully controlling for endogeneity bias)

\begin{tabular}{|l|c|c|c|c|}
\hline \multirow{2}{*}{} & \multicolumn{2}{|c|}{ High Income } & \multicolumn{2}{c|}{ Non-High Income } \\
\cline { 2 - 5 } & Value & Count & Value & Count \\
\cline { 2 - 5 } & $(1)$ & $(2)$ & $(1)$ & $(2)$ \\
\hline \multirow{2}{*}{ RTA $(0,1)$} & 0.753 & $0.289^{*}$ & $0.421^{* *}$ & -0.121 \\
& $(0.493)$ & $(0.152)$ & $(0.196)$ & $(0.098)$ \\
\hline \multirow{2}{*}{ RTA ${ }_{t-1}(0,1)$} & -0.066 & $-0.746^{* * *}$ & $0.449 *$ & 0.152 \\
\hline \multirow{2}{*}{ BIT $(0,1)$} & $(0.525)$ & $(0.257)$ & $(0.271)$ & $(0.147)$ \\
\hline \multirow{2}{*}{ BIT ${ }_{t-1}(0,1)$} & -0.562 & 0.419 & -0.063 & 0.135 \\
\hline Fixed Effects & $(0.498)$ & $(0.340)$ & $(0.289)$ & $(0.090)$ \\
\hline Country-Pair $(i j)$ & $-1.242^{* *}$ & $-0.437 * *$ & -0.228 & -0.013 \\
\hline Home-Period $(i t)$ & $(0.562)$ & $(0.215)$ & $(0.189)$ & $(0.078)$ \\
\hline Host-Period $(j t)$ & & & & \\
\hline Observations & Yes & Yes & Yes & Yes \\
\hline R-square & Yes & Yes & Yes & Yes \\
\hline & Yes & Yes & Yes & Yes \\
\hline
\end{tabular}

(Notes) (i) Country pair clustered standard errors are in parentheses.

(ii) $* * *$, and $* * *$ indicate that the variable is statistically significant at $10 \%, 5 \%$, and $1 \%$, respectively.

(iii) Count represents the number of greenfield investment projects.

\section{Conclusion}

While it has been relatively well documented that RTAs would attract FDI, there have been very few studies on how RTAs could affect a specific entry mode in highincome versus non-high income country groups. Using balanced bilateral panel data for greenfield investment flow from 25 major OECD countries to 140 countries over a span of 10 years with 3 years interval, we have analyzed how common memberships 
in RTAs affect bilateral greenfield investment flows to high-income versus non-high income countries. In addition, we have emphasized on the need to effectively account for endogeneity of RTAs. We rely on PPML estimator which produces unbiased and consistent estimate when dependent variable comprises of large proportion of zero observations as in the case of the present study.

First, we find that common membership in RTAs discourages greenfield investment in OECD-high income country pairs, while it promotes in OECD-non-high income countries pairs. Second, we also find lead as well as lag effects of RTAs on bilateral greenfield investment in both high-income (negative effect) and non-high income (positive effect) host countries. Third, our results show that failure to adjust for endogeneity bias would underestimate the impacts of RTAs on bilateral greenfield investment flows.

Therefore, non-high income countries can attract more greenfield investment by joining an RTA in which the target OECD home country is also a member. Our finding suggests that difference in economic growth stage of country pairs should receive due consideration in investigating the effect of RTA common membership on bilateral FDI flows. In addition, the issue of endogeneity bias should be an integral part of evaluating the impacts of RTAs on FDI flows.

Received 19 August 2015, Revised 23 October 2015, Accepted 28 October 2015

\section{References}

Anderson, James E., and Eric V. Wincoop. "Gravity with Gravitas: A Solution to the Border Puzzle." American Economic Review 93, no. 1(2003): 170-192.

Anderson, James E., and Yoto V. Yotov. "Terms of Trade and Global Efficiency Effects of Free Trade Agreements." NBER Working Paper No. 7003, (2011).

Bae, Chankwon, and Yong Joon Jang. "The Impact of Free Trade Agreements on Foreign Direct Investment: The Case of Korea." Journal of East Asian Economic Integration 17, no. 4 (2013): 417-445.

Baier, Scott L., and Jeffrey H. Bergstrand. "On the Endogeneity of International Trade 
Flows and Free Trade Agreements." Manuscript, 2002.

Baier, Scott L., and Jeffrey H. Bergstrand. "Do Free Trade Agreements Actually Increase members' International Trade?.” Journal of international Economics 71, no.1 (2007): 7295.

Baier, Scott L., and Jeffrey H. Bergstrand, and Michael Feng. "Economic Integration Agreements and the Margins of International Trade." Journal of International Economics 93, no.2 (2014): 339-350.

Baltagi, Badi H., Peter Egger, and Michael Pfaffermayr. "Estimating Regional Trade Agreement Effects on FDI in an Interdependent World." Journal of Econometrics 145, no. 1(2008): 194-208.

Bergstrand, Jeffrey H., and Peter Egger. "A Knowledge-and-Physical-Capital Model of International Trade Flows, Foreign Direct Investment, and Multinational Enterprises.” Journal of International Economics 73, no.2 (2007): 278-308.

Berger, Axel, Matthias Busse, Peter Nunnenkamp, and Martin Roy. "Do Trade and Investment Agreements Lead to More FDI? Accounting for Key Provisions inside the Black Box." International Economics and Economic Policy 10, no. 2 (2013): 247-275.

Blomstrom, Magnus, and Ari Kokko. "Regional Integration and Foreign Direct Investment.” No. w6019. National Bureau of Economic Research, 1997.

Carr, David L., James R. Markusen, and Keith E. Maskus. "Estimating the KnowledgeCapital Model of the Multinational Enterprise." American Economic Review 91, no.3 (2001): 693-708.

Chen, Maggie X. "Regional Economic Integration and Geographic Concentration of Multinational Firms" European Economic Review 53, no.3 (2009): 355-375.

Cook, Nathaniel PS, and John Douglas Wilson. "Using Trade Policy to Influence Firm Location." Economics Letters 119, no.1 (2013): 45-47.

Egger, Hartmut, Peter Egger, and David Greenaway. "The Trade Structure Effects of Endogenous Regional Trade Agreements.” Journal of International Economics 74, no.2 (2008): 278-298.

Eicher, Theo S., Christian Henn, and Chris Papageorgiou. "Trade Creation and Diversion Revisited: Accounting for Model Uncertainty and Natural Trading Partner 
Effects." Journal of Applied Econometrics 27, no. 2(2012): 296-321.

Ekholm, Karolina, Rikard Forslid, and James R. Markusen. "Export-Platform Foreign Direct Investment." Journal of the European Economic Association 5, no.4 (2007): 776795.

Irarrazabal, Alfonso, Andreas Moxnes, and Luca David Opromolla. "The Margins of Multinational Production and the Role of Intra-firm Trade." Journal of Political Economy 121, no.1 (2013): 74-126.

Ito, Tadashi. "Export Platform Foreign Direct Investment: Theory and Evidence." The World Economy 36, no.5 (2013): 563-581.

Jang, Yong Joon. "The Impact of Bilateral Free Trade Agreements on Bilateral Foreign Direct Investment among Developed Countries." The World Economy 34, no.9 (2011): 1628-1651.

Kim, Young-Han. "Cross-border M\&A vs. Greenfield FDI: Economic Integration and Its Welfare Impact.” Journal of Policy Modeling 31, no.1 (2009): 87-101.

Kleinert, Jörn, and Farid Toubal. "Gravity for FDI." Review of International Economics 18, no.1 (2010): 1-13.

Kreinin, Mordechai E., and Michael G. Plummer. "Effects of Regional Integration on FDI: An Empirical Approach.” Journal of Asian Economics 19, no.5 (2008): 447-454.

Lee, Jong-Wha, and Phillip Swagel. "Trade Barriers and Trade Flows across Countries and Industries." Review of Economics and Statistics 79, no.3 (1997): 372-382.

Magee, Christopher S. "Endogenous Preferential Trade Agreements: An Empirical Analysis." Contributions in Economic Analysis and Policy 2, no.1 (2003).

Marszk, Adam. "Economic Integration and Foreign Direct Investment: Review of Main Theoretical Concepts." Entrepreneurial Business and Economics Review 2, no.3 (2014):79-89.

Motta, Massimo, and George Norman. "Does Economic Integration Cause Foreign Direct Investment?." International Economic Review (1996):757-783.

Nagano, Mamoru. "Similarities and Differences among Cross-border M\&A and Greenfield FDI Determinants: Evidence from Asia and Oceania." Emerging Markets Review 16 (2013):100-118. 
Raff, Horst. "Preferential Trade Agreements and Tax Competition for Foreign Direct Investment." Journal of Public Economics 88, no.12 (2004): 2745-2763.

Silva, JMC Santos, and Silvana Tenreyro. "The Log of Gravity." Review of Economics and Statistics 88, no.4 (2006): 641-658.

te Velde, Dirk Willem, and Dirk Bezemer. "Regional Integration and Foreign Direct Investment in Developing Countries." Transnational Corporations 15, no.2 (2006): 4170.

Tekin-Koru, Ayca. "Asymmetric Effects of Trade Costs on Entry Modes: Firm level Evidence." European Economic Review 56, no.2 (2012): 277-294.

Trefler, Daniel. "Trade Liberalization and the Theory of Endogenous Protection: an Econometric Study of US Import Policy." Journal Political Economy (1993): 138-160.

United Nations Conference on Trade and Development (UNCTAD). "Regional Integration and Foreign Direct Investment in Developing and Transition Economies." New York and Geneva, 2013.

Wooldridge, Jeffrey M., Econometric Analysis of Cross Section and Panel Data. Cambridge, Mass: MIT Press, 2002.

Levy-Yeyati, Eduardo Levy, Ernesto Stein, and Christian Daude. "Regional Integration and the Location of FDI." Inter-American Development Bank Research Paper, 2003. 